\title{
Ferritchromite and chromian-chlorite formation in mélange-hosted Kalkan chromitite (Southern Urals, Russia)
}

\author{
AnNa Merlini, ${ }^{1, *}$ Giovanni Grieco, ${ }^{1}$ AND VAleria Diella ${ }^{2}$ \\ ${ }^{1}$ Dipartimento di Scienze della Terra, Università degli Studi di Milano, via Botticelli 23, 20133 Milano, Italy \\ ${ }^{2} \mathrm{CNR}$, Istituto per la dinamica dei processi ambientali, Section of Milano, via Botticelli 23, 20133 Milano, Italy
}

\begin{abstract}
Spinel is often used as a magmatic indicator of crystallization processes, without considering the effects of metamorphic alteration on spinel geochemical features. Serpentinized mélanges in the southern Urals host different kinds of disseminated to massive chromitite mineralization. In mélange environments, intense metamorphic alteration above $300{ }^{\circ} \mathrm{C}$ leads to major changes in chromite chemistry and to the growth of secondary phases such as ferritchromite and chromian-chlorite. Based on textural and chemical analyses, mélange-hosted Kalkan chromitites exhibit a hydration and oxidation reaction that can explain the formation of ferritchromite and chromian-chlorite from chromite and serpentine:

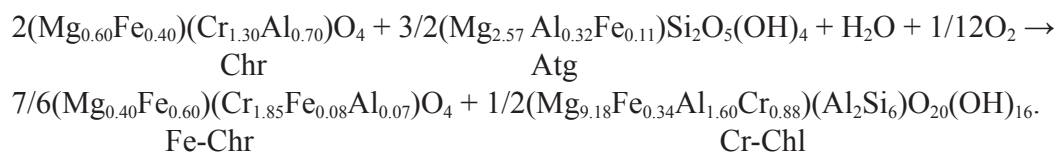

Textural analyses fit well with the proposed reaction and show that it usually proceeds very close to completion. The degree of alteration of chromite into ferritchromite is controlled by the initial chromite to serpentine ratio. In chromitites, high ratios prevent complete transformation of chromite into ferritchromite. The most likely environment for such reaction is a prograde metamorphic event post-dating serpentinization of the Kalkan ophiolite, possibly related to emplacement within an accretionary wedge.
\end{abstract}

Keywords: Chromitite, chromite, ferritchromite, chromian-chlorite, alteration, ophiolite

\section{INTRODUCTION}

Chromite is a common accessory mineral in peridotites. Its chemical composition varies depending on the physical conditions and petrogenesis (e.g., Irvine 1965, 1967; Ozawa 1983; Dick and Bullen 1984; Arai 1992, 1994). Unaltered, primary igneous chromite can be considered as a petrogenetic indicator mineral because the spinel composition reflects the degree of partial melting that the mantle experienced to produce the chromium spinel-bearing rock (Burkhard 1993). However, a discussion of the influence of metamorphic modification and alteration of chromite is ongoing (e.g., Onyeagocha 1974; Ulmer 1974; Evans and Frost 1975; Hoffman and Walker 1978; Loferski and Lipin 1983; Kimball 1990; Burkhard 1993; Oze et al. 2004). In mélange environments, intense metamorphic alteration leads to major changes in chromite chemistry and to the growth of secondary phases such as ferritchromite and chromian-chlorite.

Chromite forms chromitite layers in ophiolite complexes. The chromitites occur as lenticular or pod-shaped bodies, closely associated with dunite within the transition zone between layered gabbros and residual peridotites (e.g., Thayer 1964) or within the deeper mantle sequence cutting the deformed and/or layered

\footnotetext{
*E-mail: anna.merlini@unimi.it
}

structure of the host peridotites (Cassard et al. 1981). This paper discusses the influence of alteration and metamorphic overprints on chromitite developed in the Kalkan ophiolite of the southern Urals and its enveloping serpentinitic mélange. In this study, the mélange-hosted Kalkan chromitites are investigated using textural and chemical analyses to establish likely reactions that produce ferritchromite and chromian-chlorite.

\section{Alteration OF CHROMite}

High-Cr spinel and chromite are among the first minerals to crystallize over a wide range of conditions from mafic to ultramafic magmas (Irvine 1965). The minerals show a wide range of solid solution (O'Neill and Wall 1987; Mattioli and Wood 1988; Wood 1990; Sack and Ghiorso 1991; Poustovetov 2000). Chromite, as reported by Barnes (2000) and by Oze et al. (2004), is relatively resistant to alteration compared to other high-temperature igneous phases such as olivine, and may survive low-grade metamorphic processes related to serpentinization (Hoffman and Walker 1978; Malpas 1992; Oze et al. 2004).

Ferritchromite was reported for the first time by Spangeberg (1943) and refers to an "opaque substance that, according to chemical and physical properties, must lie between chromite and magnetite." High reflectivity and low hardness are characteristic 
of this mineral (Pouyan et al. 1988). Ferritchromite, bordering chromite grains, can be the product of low-temperature alteration (e.g., Barnes 2000) where cataclastic deformation, together with hydrothermal alteration, likely favors the formation of chlorite closely associated with ferritchromite (Christofides et al. 1994). Most studies indicate that ferritchromite is produced as a consequence of a metamorphic overprint (e.g., Evans and Frost 1975; Barnes 2000).

Chromite alteration is influenced by the degree of metamorphism and, as reported by Barnes (2000), chromite in greenschist facies conditions spans from very $\mathrm{Mg}$ rich to very Fe rich, with $\mathrm{Co}, \mathrm{Zn}$, and $\mathrm{Mn}$ correlating negatively with $\mathrm{Mg} /\left(\mathrm{Mg}+\mathrm{Fe}^{2+}\right)$ and $\mathrm{Ni}$ and $\mathrm{Ti}$ correlating positively with $\mathrm{Fe}^{3+}$. Under amphibolite facies conditions, the $\mathrm{Mg} /\left(\mathrm{Mg}+\mathrm{Fe}^{2+}\right)$ values are generally lower, but $\mathrm{Co}, \mathrm{Mn}$, and $\mathrm{Zn}$ reach much higher values than in greenschist facies conditions.

During metamorphism, chlorite and ferritchromite can be formed during the reaction of chromite with silicates and metamorphic fluids (Barnes 2000; Barnes and Roeder 2001). Kimball (1990) proposed that the alteration of spinel to form chlorite could be described by the following reaction:

$$
\underset{\mathrm{Spl}}{\mathrm{MgAl}_{2} \mathrm{O}_{4}}+4 \mathrm{MgO}+3 \mathrm{SiO}_{2}+4 \mathrm{H}_{2} \mathrm{O}=\mathrm{Mg}_{5} \mathrm{AlAlSi}_{3} \mathrm{O}_{10}(\mathrm{OH})_{8}
$$

$\mathrm{MgO}, \mathrm{SiO}_{2}$, and $\mathrm{H}_{2} \mathrm{O}$ presumably come from the fluid phase.

Mellini et al. (2005) suggested that, during post-serpentinization, Al diffuses out of magmatic spinel resulting in an ( $\mathrm{Fe}, \mathrm{Cr}$ )-rich spinel (ferritchromite or $\mathrm{Cr}$-magnetite) and promotes the formation of chlorite rims. Chromium-magnetite has been defined by Mellini et al. (2005) as a spinel with the following stoichiometric formula: $\mathrm{Mg}_{0.03} \mathrm{Fe}_{0.97}^{2+} \mathrm{Al}_{0.11} \mathrm{Cr}_{0.89} \mathrm{Fe}_{1}^{3+} \mathrm{O}_{4}$. Ferritchromite exists in hydrothermally altered rims of primary magmatic Al-spinel. Mellini et al. (2005) suggest that metamorphic alteration of chromite occurs as a two steps process: (1) initially, unaltered chromitite pods associated with dunite are affected by regional serpentinization, and (2) a later event transforms chromite into Cr-magnetite accompanied by chlorite formation. To explain such a process, Mellini et al. (2005) proposed the following reaction:

$$
\begin{aligned}
& \mathrm{MAl}_{2} \mathrm{O}_{4}+1.5 \mathrm{M}_{3} \mathrm{Si}_{2} \mathrm{O}_{5}(\mathrm{OH})_{4}+\mathrm{H}_{2} \mathrm{O}+0.083 \mathrm{O}_{2} \rightarrow \\
& \text { Al-Spl Srp } \\
& \mathrm{M}_{5} \mathrm{AlSi}_{3} \mathrm{AlO}_{10}(\mathrm{OH})_{8}+0.167 \mathrm{M}_{3} \mathrm{O}_{4} \\
& \mathrm{Chl} \quad \mathrm{Cr}-\mathrm{Mag}
\end{aligned}
$$

with trivalent cations ( $\mathrm{Fe}$ and $\mathrm{Cr}$ ) preferentially partitioned into magnetite and $\mathrm{M}$ representing divalent $\mathrm{Fe}$ and $\mathrm{Mg}$ in spinel, serpentine, clinochlore, and divalent and trivalent $\mathrm{Fe}$ in magnetite.

\section{GEOLOGICAL BACKGROUND}

\section{The Urals}

The Urals are a linear mountain belt marking a $2500 \mathrm{~km}$ long Mid-Paleozoic orogenic zone. The zone represents the closure of an ancient ocean basin-island arc system between the European and Siberian Plates. This collision resulted in $>150$ ophiolite complexes as a series of tectonic slices within major structural units. The ophiolite complexes range in length from 10 to $15 \mathrm{~km}$ and up to $200 \mathrm{~km}$ (Voykar massif in the Polar Urals). They can be grouped into three major north-south trending belts: (1) the Western Ophiolite Belt; (2) the Root Zone Ophiolite Belt; and (3) the Eastern Uralian Belt (Fig. 1).

\section{Kalkan ophiolite}

The Kalkan ophiolite consists of a peridotite massif (the Kalkan massif) and several ophiolite fragments scattered within a serpentinite mélange of the Root Zone Ophiolite Belt (Fig. 2). The Kalkan massif is a $2 \times 1 \mathrm{~km}$ block of mantle peridotite that crops out near Kalkan Lake, $11 \mathrm{~km} \mathrm{SW}$ of Abzakovo village. It consists mainly of harzburgite with minor dunite. The dunite occurs as curvilinear lenses within the harzburgite. Only scattered Cr-rich spinel grains were found within the harzburgite and dunite. Harzburgite and dunite contain high-Mg olivine (Fo $\mathrm{O}_{9-92}$ ), enstatite, and accessory high-Cr spinel (53-56 wt \% $\mathrm{Cr}_{2} \mathrm{O}_{3}$ ). A high degree of partial melting in the harzburgite is indicated by the extremely low contents of basaltic components as implied by the whole rock composition; $\mathrm{CaO}$ contents range between 0.1 and $0.3 \mathrm{wt} \%$ and $\mathrm{Al}_{2} \mathrm{O}_{3}$ between 0.8 and $1.2 \mathrm{wt} \%$ (Chaplygina et al. 2002).

Crustal units of the Kalkan ophiolite sequence occur as several scattered fragments of wehrlite, websterite, layered gabbro, diabase, basalt, and chert. Geochemical investigations of all parts of the ophiolite indicate that they could be parts of a common, strongly depleted ophiolitic sequence hosted in a serpentinized mélange (Chaplygina et al. 2002; Saveliev et al. 1998). The serpentinite mélange has been interpreted by Chaplygina et

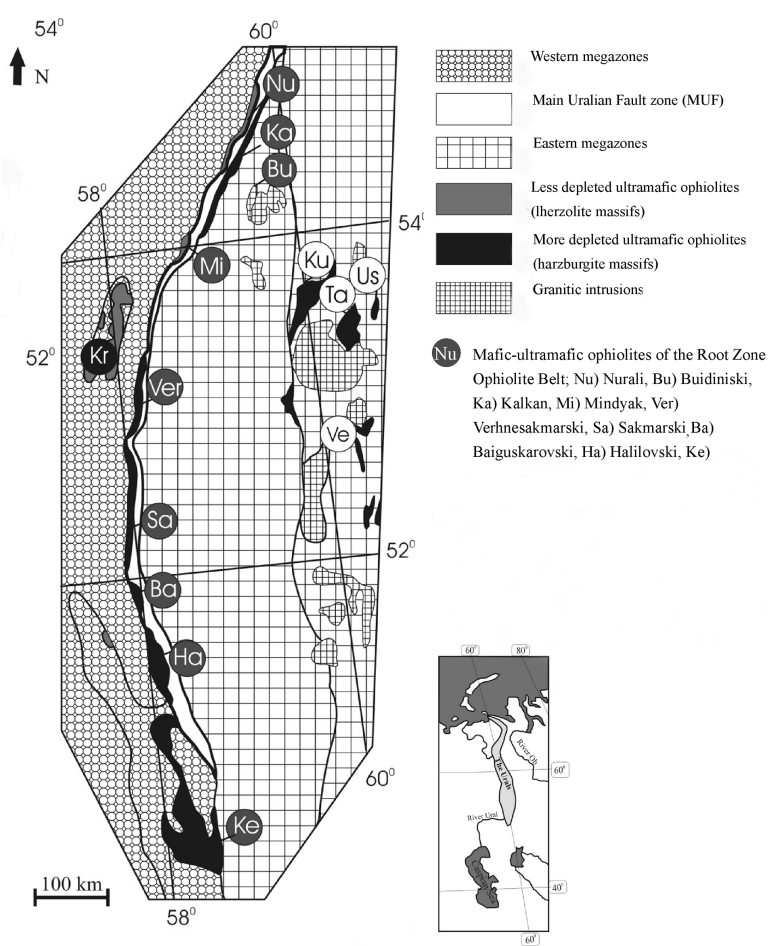

FIGURE 1. Schematic geologic map of the southern Urals with locations of mafic-ultramafic ophiolite complexes. Modified from Chaplygina et al. (2002). 
al. (2002) to be an accretionary wedge formed by a multistage process from the Early Devonian to the Late Paleozoic and is related to ophiolite emplacement. Mélange type mixing seems to have occurred during intensive tectonic deformation of oceanic lithosphere (Chaplygina et al. 2002). Chromitite units were found near Abzakovo within the serpentinite mélange enveloping the scattered fragments of the Kalkan ophiolite (Fig. 2).

\section{KALKAN CHROMITITES}

Kalkan mélange chromitite bodies primarily crop out in prospecting trenches dug during a survey for chromitite ores between 2000 and 2002. Forty samples of chromitite, collected from surface outcrops and trenches, were examined. Major chromitite occurrences were found as meter-scale lenses and schlieren hosted by a serpentine-chlorite rock. Chromitites show a wide variety of textures ranging from disseminated to massive and, in some cases, augen textures with serpentine augen within the chromitites have been observed. Euhedral-to-subhedral chromite grains are commonly fractured and dismembered. They are chemically homogeneous but extensive portions of the chromite grains have been replaced by porous ferritchromite without any evident core-to-rim zoning in replacement zones. Ferritchromite is typically accompanied by the growth of chlorite replacing serpentine. Rare serpentine relicts are found in the matrix of chromitite, away from ferritchromite (Fig. 3). No other minerals were detected due to the high degree of serpentinization and to the high concentrations of chromite in the rocks.

\section{ANALYTICAL METHODS}

Quantitative chemical WDS analyses were performed on selected polished samples using an Applied Research Laboratories electron microprobe fitted with six wavelength-dispersive spectrometers and a Tracor Northern Energy Dispersive Spectrometer at the CNR, Istituto per la Dinamica dei Processi Ambientali Labo-
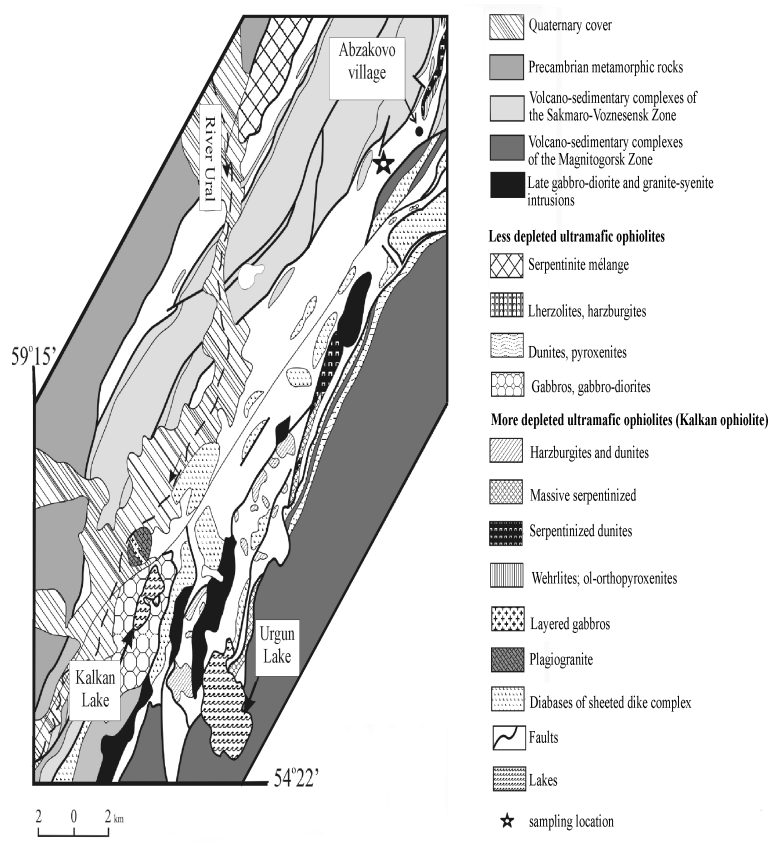

FigurE 2. Geological setting of Kalkan zone. Modified from Chaplygina et al. (2002). ratory, University of Milan. The operating conditions used were an accelerating voltage of $15 \mathrm{kV}$, a sample current on brass of $15 \mathrm{nA}$, and count times of $20 \mathrm{~s}$ on the peaks and $10 \mathrm{~s}$ on the backgrounds. A series of natural minerals (kaersutite for $\mathrm{Si}, \mathrm{Mg}, \mathrm{Na}, \mathrm{Ti}, \mathrm{K}, \mathrm{Fe}, \mathrm{Al}$; chromite for $\mathrm{Cr}$; rhodonite for $\mathrm{Mn}$; and niccolite for $\mathrm{Ni}$ ) were used as standards. Detection limits are estimated to be $0.01 \mathrm{wt} \%$ for each element. Results were processed for matrix effects using a conventional ZAF routine in the Tracor Northern TASK series of programs. More than 300 individual analyses were performed on selected samples of Kalkan chromitite bodies. Ferric iron was calculated on the basis of stoichiometry and data were normalized with the NORM program.

Qualitative X-ray powder diffraction (XRD) analyses were performed using a Philips X'pert MPD X-ray powder diffractometer to better characterize chlorite and serpentine minerals. Powdered samples were scanned from 2 to $50^{\circ} 2 \theta$ with a step size of $0.02^{\circ} 2 \theta$ and a count time of 2.0 s per step.

Detailed compositional X-ray intensity maps were obtained for selected areas to investigate the distribution of major elements ( $\mathrm{Cr}, \mathrm{Fe}, \mathrm{Mg}, \mathrm{Al}$, and $\mathrm{Si}$ ). The image acquisition conditions were $15 \mathrm{kV}$ accelerating voltage, $1 \mu \mathrm{m}^{2}$ pixel size, and a 40 $\mathrm{ms}$ dwell time. Ten to 20 back-scattered electron (BSE) images were obtained for each sample to investigate all the different textures observed in Kalkan chromitite and to look for evidence of compositional zoning.

Modal analysis of selected BSE images was performed using "Image-Pro Plus" software. In selected BSE images (8-bit grayscale images), each grayscale pixel value represents a level of grayness or brightness, ranging from completely black $($ value $=0)$ to completely white $($ value $=255$ ). Intensity values are represented with 8 -bit integers. The number of bits used to represent the pixel values in an image is referred to as its pixel depth or bits per pixel (BPP).

The mineral phases chromite, ferritchromite, chromian-chlorite, and serpentine were isolated within the images according to their characteristic range of gray levels. The intensity values of each image were evaluated through analysis of each associated gray level intensity histogram that describes the frequency distribution of the intensities. Through this process, gray level intensities corresponding to different phases were isolated and associated areas were calculated (Fig. 4). To calculate the area corresponding to the high porosity detected in ferritchromite, morphological filtering operations were applied on gray level intensities that reduce or boost the rate of brightness change in an image. Different types of morphological filters are available in "Image-Pro Plus" software. This study used the "Close" filter, the effect of which is to modify the shape of the objects in a selected gray level intensity range within the image. Ferritchromite, characterized by high porosity, shows high values of gray intensity always close to 255 (completely white). To eliminate pores, characterized by dark low values close to 0 (completely black), a morphological filter (named "Close" filter), with the effect of closing holes, has been applied to eliminate such low values of gray intensity. This operation allowed for evaluation of the area of chromite prior to ferritchromite formation. Areas determined by modal analyses are likely to be proportional to volumes since chromite forms equigranular grains (Higgins 2006).

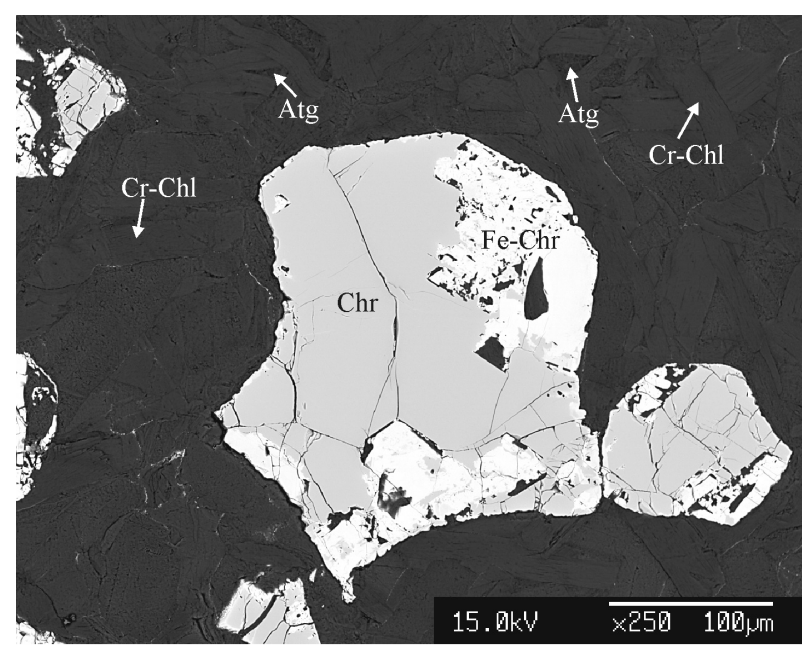

FIGURE 3. Highly porous ferritchromite replacement of a chromite grain surrounded by chromian-chlorite with serpentine relics. Fe-Chr = ferritchromite, $\mathrm{Cr}-\mathrm{Chl}=$ chromian-chlorite, $\mathrm{Atg}=$ antigorite. 


\section{RESULTS}

\section{Mineral chemistry}

Chromite and ferritchromite. Magmatic chromite grains have $100[\mathrm{Cr} /(\mathrm{Cr}+\mathrm{Al})]$ atomic ratios ranging between 73 and 79 and $100\left[\mathrm{Mg} /\left(\mathrm{Mg}+\mathrm{Fe}^{2+}\right)\right]$ atomic ratios between 58 and 70 (Fig. 5). $\mathrm{Cr}_{2} \mathrm{O}_{3}$ ranges between 55 and $62 \mathrm{wt} \% ; \mathrm{MgO}$ between 11.2 and $14.7 \mathrm{wt} \% ; \mathrm{Al}_{2} \mathrm{O}_{3}$ between 10.9 and $13.5 \mathrm{wt} \% ; \mathrm{FeO}$ between 10 and $19 \mathrm{wt} \%$; and $\mathrm{Fe}_{2} \mathrm{O}_{3}$ between 2 and $5 \mathrm{wt} \%$. Analytical traverses across whole crystals revealed no detectable zoning from core to rim (Table 1). See Tables 2 and 3 for chromite cores and ferritchromite rims, respectively.

Highly porous ferritchromite has $100[\mathrm{Cr} /(\mathrm{Cr}+\mathrm{Al})]$ atomic ratios ranging between 88 and 95 and $100\left[\mathrm{Mg} /\left(\mathrm{Mg}+\mathrm{Fe}^{2+}\right)\right]$ between 37 and 45 (Fig. 5). $\mathrm{Cr}_{2} \mathrm{O}_{3}$ ranges between 56 and $63 \mathrm{wt} \%$; $\mathrm{MgO}$ between 3 and $8 \mathrm{wt} \% ; \mathrm{Al}_{2} \mathrm{O}_{3}$ between 1 and $7 \mathrm{wt} \%$; $\mathrm{FeO}$ from 17 to $32 \mathrm{wt} \%$; and $\mathrm{Fe}_{2} \mathrm{O}_{3}$ between 4 and $13 \mathrm{wt} \%$. Such ranges in mineral chemistry do not reflect mineral zoning, but random variations among crystals

Chlorite. Chlorite grains range in length from 10 to $100 \mu \mathrm{m}$, and form locally marginal to ferritchromite-chromite grains. The chlorites are compositionally homogeneous chromian-chlorites marked by relatively high $\mathrm{Cr}_{2} \mathrm{O}_{3}(2-6 \mathrm{wt} \%), \mathrm{MgO}(34-34.5 \mathrm{wt} \%)$, $\mathrm{SiO}_{2}(33-36.5 \mathrm{wt} \%), \mathrm{Al}_{2} \mathrm{O}_{3}(6.5-14.8 \mathrm{wt} \%)$, and $\mathrm{FeO}(1.5-5.0$ $w t \%$ ). Concentrations of $\mathrm{TiO}_{2}, \mathrm{NiO}$, and $\mathrm{CaO}$ are very low and sometimes below the detection limits of $0.01 \mathrm{wt} \%$.

Serpentine. Serpentine minerals are minor phases that occur within the matrix of chromitite. Characterization of this phase has been difficult due to its low modal abundance and its tex- tural relationship with chromite and chromian-chlorite grains. Qualitative X-ray diffraction data suggest that it is primarily antigorite. In thin section, a non-pseudomorphic texture typical of antigorite (Wicks and Whittaker 1977) has been observed and is characterized by elongated, anhedral grains with random to sub-parallel orientations depending on the amount of serpentine. Most of the serpentine grains contain relatively high $\mathrm{Al}_{2} \mathrm{O}_{3}$ (up to $4.0 \mathrm{wt} \%$ ), consistent with antigorite. $\mathrm{MgO}$ ranges from 32.0 to $39.5 \mathrm{wt} \% ; \mathrm{SiO}_{2}$ between 41.0 and $42.0 \mathrm{wt} \% ; \mathrm{Cr}_{2} \mathrm{O}_{3}$ between 1.0 and $1.5 \mathrm{wt} \%$; and $\mathrm{FeO}$ between 1.0 and $4.3 \mathrm{wt} \%$. $\mathrm{TiO}_{2}, \mathrm{NiO}$, and $\mathrm{CaO}$ are close to detection limits of $0.01 \mathrm{wt} \%$.

Although not detected with XRD, a few grains of serpentine have lower $w t \% \mathrm{Al}_{2} \mathrm{O}_{3}$ and are likely to be lizardite or chrysotile. However, no significant textural differences have been observed between these and the antigorite grains described above. These grains contain $\mathrm{Al}_{2} \mathrm{O}_{3}$ between 0.05 and $0.65 \mathrm{wt} \%, \mathrm{Cr}_{2} \mathrm{O}_{3}$ between 0.30 and $0.50 \mathrm{wt} \%$, and $\mathrm{NiO}$ between 0.20 and $0.25 \mathrm{wt} \%$ (Table 4). Detailed X-Ray compositional maps have been performed on selected grains to highlight the distribution of $\mathrm{Cr}, \mathrm{Al}, \mathrm{Mg}$, and $\mathrm{Fe}$. Such compositional maps aided the identification of small serpentine relics in the chloritic matrix and to observe compositional differences between chromite and ferritchromite (Fig. 6).

\section{Modal analysis results}

Modal analyses were performed using "Image-Pro Plus" software to evaluate the volumes of phases involved in the chromian-chlorite and ferritchromite forming reaction. To establish changes in the volume ratios of phases, a full range of textures, disseminated to massive, were used (Table 5). Chromite
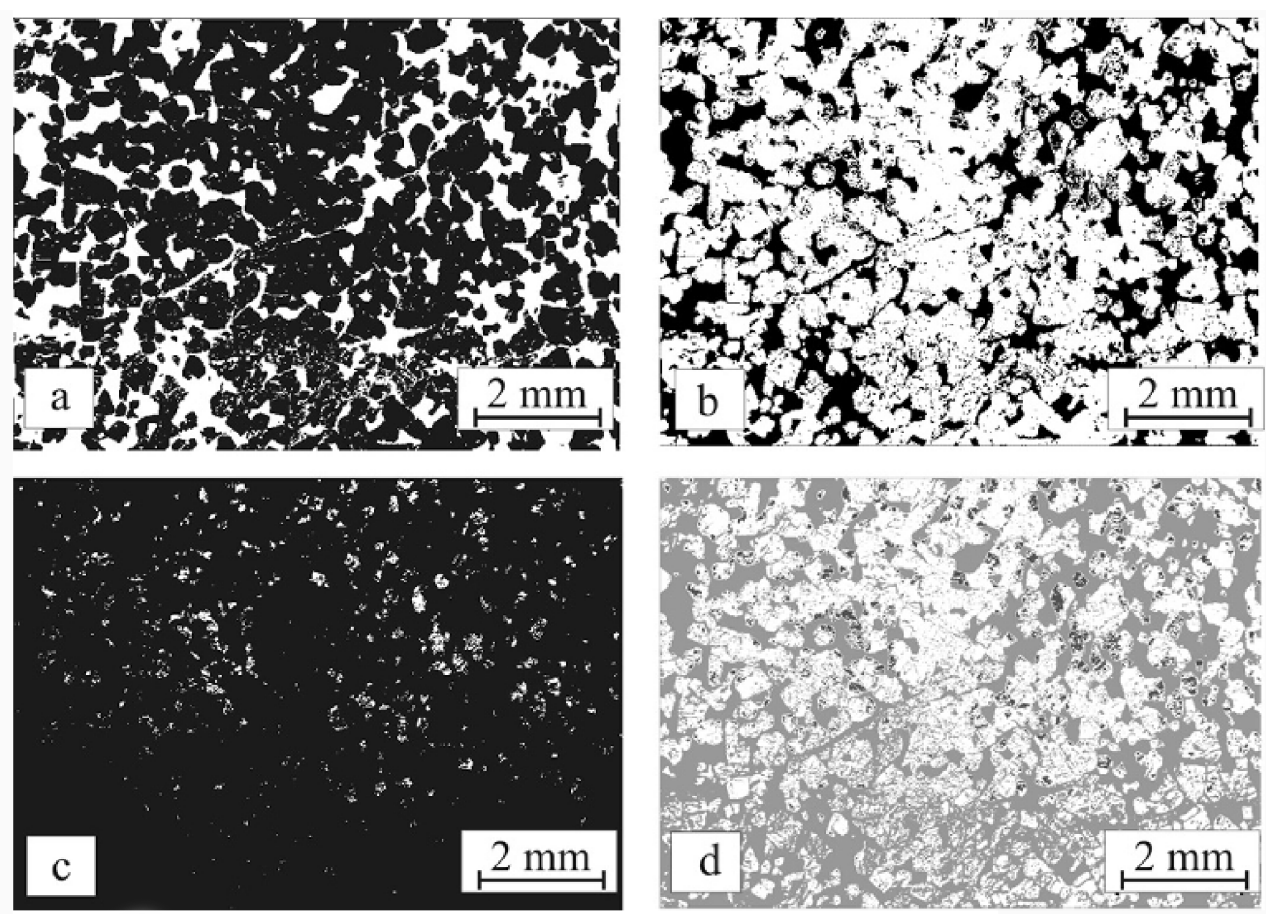

FIGURE 4. Image analysis example showing threshold process results: (a) chromian-chlorite in white, chromite and ferritchromite in black; (b) chromite in white, chromian-chlorite and ferritchromite in black; (c) ferritchromite in white, chromite and chromian-chlorite in black; (d) sum of $\mathbf{a}, \mathbf{b}$, and $\mathbf{c}$; chromian-chlorite in gray, chromite in white and ferritchromite in black. Mineral phases were isolated, according to their characteristic range of gray level intensity and each associated area has been calculated. 


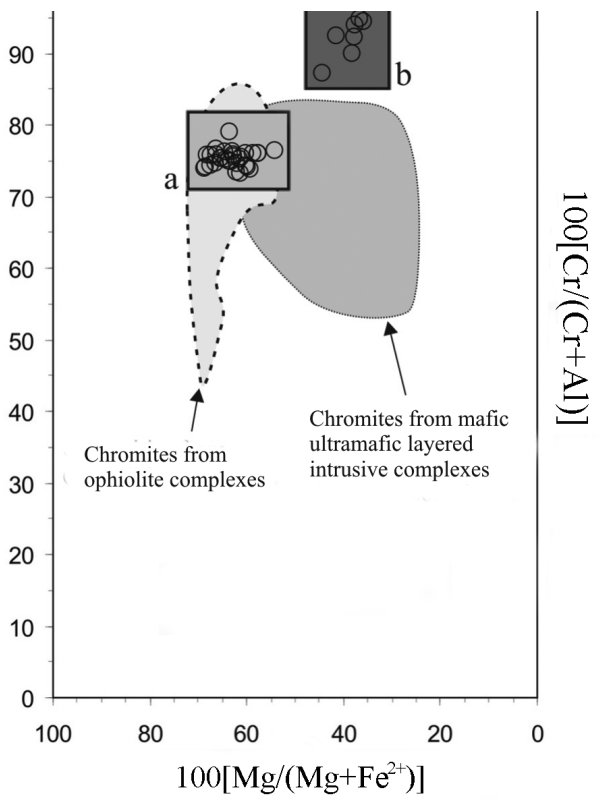

FIGURE 5. $100\left[\mathrm{Mg} /\left(\mathrm{Mg}+\mathrm{Fe}^{2+}\right)\right]$ vs. $100[\mathrm{Cr} /(\mathrm{Cr}+\mathrm{Al})]$ of Kalkan chromite grains: (a) chromite and (b) ferritchromite. Chromite fields are from Dick and Bullen (1984).

volume ranges from 50 to $93 \%$, ferritchromite from 1 to $10 \%$, and chromian-chlorite from 6 to $40 \%$. Such volumes are termed as modal final volumes $\left(V_{\mathrm{mf}}\right)$ and are shown in Table 5. Because serpentine is present only as minor relics, $V_{\mathrm{mf}}^{\text {srp }}$ is assumed to be 0 . Because relative volumes of phases involved in the reactions depend on their stoichiometry, modal analyses of the products relative to reactants were used to check the validity of the reaction and to assess its progress.

\section{DISCUSSION}

\section{From chromite to ferritchromite: A reaction based on chemical and textural analysis}

Based on textural and volume analyses and actual mineral chemistry, the following reaction is suggested:

$$
\begin{aligned}
& 2\left(\mathrm{Mg}_{0.60} \mathrm{Fe}_{0.40}\right)\left(\mathrm{Cr}_{1.30} \mathrm{Al}_{0.70}\right) \mathrm{O}_{4}+ \\
& \mathrm{Chr} \\
& 3 / 2\left(\mathrm{Mg}_{2.57} \mathrm{Al}_{0.32} \mathrm{Fe}_{0.11}\right) \mathrm{Si}_{2} \mathrm{O}_{5}(\mathrm{OH})_{4}+\mathrm{H}_{2} \mathrm{O}+1 / 12 \mathrm{O}_{2} \rightarrow \\
& \text { Atg } \\
& 7 / 6\left(\mathrm{Mg}_{0.40} \mathrm{Fe}_{0.60}\right)\left(\mathrm{Cr}_{1.85} \mathrm{Fe}_{0.08} \mathrm{Al}_{0.07}\right) \mathrm{O}_{4} \\
& \mathrm{Fe}-\mathrm{Chr} \\
& +1 / 2\left(\mathrm{Mg}_{9.18} \mathrm{Fe}_{0.34} \mathrm{Al}_{1.60} \mathrm{Cr}_{0.88}\right)\left(\mathrm{Al}_{2} \mathrm{Si}_{6}\right) \mathrm{O}_{20}(\mathrm{OH})_{16} \\
& \mathrm{Cr}-\mathrm{Chl}
\end{aligned}
$$

This reaction differs from reaction 1 in that it does not re-

\begin{tabular}{|c|c|c|c|c|c|c|c|c|c|c|c|c|}
\hline wt $\%$ & 1 & 2 & 3 & 4 & 5 & 6 & 7 & 8 & 9 & 10 & 11 & 12 \\
\hline $\mathrm{SiO}_{2}$ & 0.19 & 0.34 & 0.09 & 0.07 & 0.2 & 0.25 & 0.31 & 0.12 & 0.29 & 0.03 & 0.03 & 0.02 \\
\hline $\mathrm{TiO}_{2}$ & 0.13 & 0.18 & 0.08 & 0.15 & 0.26 & 0.09 & 0.16 & 0.28 & 0.07 & 0.13 & 0.13 & 0.13 \\
\hline $\mathrm{Al}_{2} \mathrm{O}_{3}$ & 12.97 & 13.32 & 13.18 & 13.1 & 13.35 & 12.97 & 13.56 & 13.64 & 13.87 & 12.9 & 12.91 & 12.68 \\
\hline $\mathrm{Cr}_{2} \mathrm{O}_{3}$ & 56.65 & 57.06 & 56.09 & 56.92 & 57.58 & 56.71 & 56.9 & 56.27 & 56.94 & 56.02 & 55.84 & 54.68 \\
\hline $\mathrm{Fe}_{2} \mathrm{O}_{3}$ & 4.87 & 2.75 & 4.22 & 3.63 & 2.3 & 3.36 & 2.43 & 3.44 & 3.03 & 2.28 & 2.59 & 2.65 \\
\hline $\mathrm{FeO}$ & 11.6 & 13.47 & 12.51 & 12.75 & 13.67 & 13.27 & 14.21 & 13.06 & 12.81 & 14.69 & 14.51 & 17.33 \\
\hline $\mathrm{MgO}$ & 13.07 & 12.93 & 12.64 & 12.86 & 12.92 & 12.65 & 12.76 & 13.23 & 13.28 & 12.37 & 12.47 & 10.46 \\
\hline Total & 99.48 & 100.05 & 98.81 & 99.48 & 100.28 & 99.3 & 100.33 & 100.04 & 100.29 & 98.42 & 98.48 & 97.95 \\
\hline $\mathrm{Si}$ & 0.006 & 0.010 & 0.003 & 0.002 & 0.006 & 0.008 & 0.001 & 0.003 & 0.009 & 0.001 & 0.001 & 0.001 \\
\hline $\mathrm{Ti}$ & 0.003 & 0.004 & 0.002 & 0.004 & 0.006 & 0.002 & 0.004 & 0.007 & 0.002 & 0.003 & 0.003 & 0.003 \\
\hline $\mathrm{Al}$ & 0.485 & 0.497 & 0.498 & 0.492 & 0.498 & 0.489 & 0.506 & 0.508 & 0.514 & 0.494 & 0.494 & 0.494 \\
\hline $\mathrm{Cr}$ & 1.421 & 1.429 & 1.422 & 1.435 & 1.442 & 1.435 & 1.425 & 1.408 & 1.416 & 1.441 & 1.434 & 1.431 \\
\hline $\mathrm{Fe}^{3+}$ & 0.120 & 0.070 & 0.10 & 0.09 & 0.05 & 0.08 & 0.06 & 0.08 & 0.07 & 0.06 & 0.06 & 0.07 \\
\hline $\mathrm{Fe}^{2+}$ & 0.310 & 0.360 & 0.34 & 0.34 & 0.36 & 0.36 & 0.38 & 0.35 & 0.34 & 0.40 & 0.39 & 0.48 \\
\hline $\mathrm{Mg}$ & 0.620 & 0.610 & 0.600 & 0.610 & 0.610 & 0.600 & 0.600 & 0.620 & 0.620 & 0.600 & 0.600 & 0.520 \\
\hline
\end{tabular}
quire dissolved cation contributions from the fluids and assumes isochemical metamorphism. Unlike reaction 2, it takes into account $\mathrm{Mg}$ and $\mathrm{Fe}$, as well as $\mathrm{Fe}^{2+}$ and $\mathrm{Fe}^{3+}$. The stoichiom-

\begin{tabular}{|c|c|c|c|c|c|c|c|c|c|c|c|}
\hline wt\% & 1 & 2 & 3 & 4 & 5 & 6 & 7 & 8 & 9 & 10 & 11 \\
\hline $\mathrm{SiO}_{2}$ & 0.19 & 0.14 & 0.12 & 0.23 & 0.26 & 0.41 & 0.14 & 0.07 & - & - & 0.23 \\
\hline $\mathrm{TiO}_{2}$ & 0.11 & 0.17 & 0.28 & 0.36 & 0 & 0.11 & 0.16 & 0.06 & 0.15 & 0.11 & 0.14 \\
\hline $\mathrm{Al}_{2} \mathrm{O}_{3}$ & 3.17 & 4.42 & 1.03 & 2.32 & 2.28 & 5.98 & 2.55 & 2.23 & 2.31 & 4.05 & 3.21 \\
\hline $\mathrm{Cr}_{2} \mathrm{O}_{3}$ & 58.24 & 60.12 & 61.83 & 59.68 & 62.83 & 61.05 & 59.7 & 61.63 & 59.55 & 60.36 & 56.73 \\
\hline $\mathrm{Fe}_{2} \mathrm{O}_{3}$ & 11.8 & 7.58 & 6.63 & 9.4 & 7.96 & 4.31 & 8.71 & 5.23 & 8.51 & 5.45 & 12.96 \\
\hline $\mathrm{FeO}$ & 18.04 & 20.04 & 22.89 & 20.75 & 18.89 & 18.22 & 20.58 & 21.21 & 20.22 & 20.95 & 19.37 \\
\hline $\mathrm{MgO}$ & 8.06 & 7.54 & 4.82 & 7.19 & 7.05 & 8.87 & 7.28 & 6.6 & 7.47 & 7.11 & 7.38 \\
\hline Total & 99.61 & 100.01 & 97.6 & 99.93 & 99.27 & 98.95 & 99.12 & 97.03 & 98.21 & 98.03 & 100.02 \\
\hline $\mathrm{Si}$ & 0.01 & - & - & 0.01 & 0.01 & 0.01 & - & - & - & - & 0.01 \\
\hline $\mathrm{Ti}$ & - & - & 0.01 & 0.01 & - & - & - & - & - & - & - \\
\hline $\mathrm{Al}$ & 0.13 & 0.18 & 0.04 & 0.10 & 0.09 & 0.24 & 0.11 & 0.09 & 0.10 & 0.17 & 0.13 \\
\hline $\mathrm{Cr}$ & 1.58 & 1.63 & 1.78 & 1.64 & 1.73 & 1.64 & 1.66 & 1.76 & 1.67 & 1.68 & 1.55 \\
\hline $\mathrm{Fe}^{3+}$ & 0.31 & 0.20 & 0.18 & 0.25 & 0.21 & 0.11 & 0.23 & 0.14 & 0.23 & 0.14 & 0.34 \\
\hline $\mathrm{Fe}^{2+}$ & 0.52 & 0.57 & 0.70 & 0.60 & 0.55 & 0.52 & 0.60 & 0.64 & 0.60 & 0.62 & 0.56 \\
\hline $\mathrm{Mg}$ & 0.41 & 0.39 & 0.26 & 0.37 & 0.37 & 0.45 & 0.38 & 0.35 & 0.39 & 0.37 & 0.38 \\
\hline
\end{tabular}
etry of reaction 3 permits estimation of the degree of reaction progress.

Initial modal volumes $\left(V_{\mathrm{mi}}\right)$ were estimated by examination of

TABLE 1. Selected microprobe analyses of chromite cores

Notes: $\mathrm{Chr}=$ chromite, $\mathrm{Fe}-\mathrm{Chr}=$ ferritchromite. $\mathrm{Fe}^{3+}$ calculated on the basis of stoichiometry. Each analysis represents individual crystal.

TABLE 2. Selected microprobe analyses of ferritchromite rims

Notes: $\mathrm{Chr}=$ chromite, $\mathrm{Fe}-\mathrm{Chr}=$ ferritchromite. $\mathrm{Fe}^{3+}$ calculated on the basis of stoichiometry. 
TABLE 3. Selected microprobe analyses of chromian-chlorite

\begin{tabular}{|c|c|c|c|c|c|c|c|c|c|c|c|}
\hline wt\% & 1 & 2 & 3 & 4 & 5 & 6 & 7 & 8 & 9 & 10 & 11 \\
\hline$\overline{\mathrm{SiO}_{2}}$ & 33.97 & 32.92 & 34.15 & 33.42 & 32.75 & 35.66 & 33.59 & 32.81 & 33.15 & 33.02 & 34.88 \\
\hline $\mathrm{TiO}_{2}$ & 0.05 & - & - & 0.03 & 0.01 & - & 0.01 & 0.02 & - & 0.03 & 0.03 \\
\hline $\mathrm{Al}_{2} \mathrm{O}_{3}$ & 13.80 & 14.35 & 13.73 & 13.36 & 14.46 & 10.78 & 13.72 & 14.73 & 13.81 & 14.56 & 7.86 \\
\hline $\mathrm{Cr}_{2} \mathrm{O}_{3}$ & 2.80 & 3.50 & 2.16 & 2.89 & 3.23 & 2.61 & 2.40 & 3.08 & 2.21 & 3.37 & 5.31 \\
\hline $\mathrm{FeO}$ & 1.77 & 1.65 & 1.45 & 1.79 & 1.65 & 1.54 & 1.35 & 1.62 & 1.41 & 1.57 & 3.76 \\
\hline $\mathrm{NiO}$ & 0.20 & 0.20 & 0.30 & 0.20 & 0.20 & 0.24 & 0.27 & 0.21 & 0.27 & 0.21 & 0.05 \\
\hline $\mathrm{MgO}$ & 34.59 & 34.13 & 35.18 & 34.25 & 34.09 & 35.33 & 34.58 & 34.33 & 34.75 & 34.29 & 34.81 \\
\hline $\mathrm{CaO}$ & 0.02 & 0.01 & 0.01 & - & 0.02 & 0.02 & 0.01 & 0.02 & 0.02 & 0.02 & - \\
\hline $\mathrm{H}_{2} \mathrm{O}$ & 12.68 & 12.60 & 12.71 & 12.49 & 12.56 & 12.55 & 12.54 & 12.63 & 12.52 & 12.65 & 12.41 \\
\hline Total & 99.88 & 99.36 & 99.69 & 98.43 & 98.97 & 98.74 & 98.47 & 99.46 & 98.14 & 99.73 & 99.11 \\
\hline $\mathrm{Si}$ & 6.43 & 6.27 & 6.45 & 6.42 & 6.25 & 6.82 & 6.42 & 6.23 & 6.35 & 6.26 & 6.74 \\
\hline $\mathrm{Ti}$ & 0.01 & - & - & - & - & - & - & - & - & - & - \\
\hline $\mathrm{Al}$ & 3.08 & 3.22 & 3.05 & 3.02 & 3.25 & 2.43 & 3.09 & 3.30 & 3.12 & 3.25 & 1.79 \\
\hline $\mathrm{Cr}$ & 0.42 & 0.53 & 0.32 & 0.44 & 0.49 & 0.39 & 0.36 & 0.46 & 0.33 & 0.51 & 0.81 \\
\hline $\mathrm{Fe}^{2+}$ & 0.28 & 0.26 & 0.23 & 0.29 & 0.26 & 0.25 & 0.22 & 0.26 & 0.23 & 0.25 & 0.61 \\
\hline $\mathrm{Ni}$ & 0.03 & 0.03 & 0.05 & 0.03 & 0.03 & 0.04 & 0.04 & 0.03 & 0.04 & 0.03 & 0.01 \\
\hline $\mathrm{Mg}$ & 9.75 & 9.69 & 9.90 & 9.80 & 9.70 & 10.07 & 9.86 & 9.71 & 9.92 & 9.69 & 10.03 \\
\hline $\mathrm{Ca}$ & - & - & - & - & - & - & - & - & - & - & - \\
\hline
\end{tabular}

TABLE 4. Selected microprobe analyses of antigorite

\begin{tabular}{llllllll}
\hline $\mathrm{wt} \%$ & $1 \mathrm{Atg}$ & $2 \mathrm{Atg}$ & $3 \mathrm{Atg}$ & $4 \mathrm{Atg}$ & $5 \mathrm{Atg}$ & $6 \mathrm{Lz} / \mathrm{Ctl}$ & $7 \mathrm{Lz} / \mathrm{Ctl}$ \\
\hline $\mathrm{SiO}_{2}$ & 41.23 & 43.81 & 42.74 & 41.95 & 42.32 & 41.95 & 45.18 \\
$\mathrm{TiO}_{2}$ & 0.02 & 0.02 & - & 0.01 & & & \\
$\mathrm{Al}_{2} \mathrm{O}_{3}$ & 3.6 & 2.2 & 2.47 & 3.69 & 1.98 & 0.10 & 0.61 \\
$\mathrm{Cr}_{2} \mathrm{O}_{3}$ & 1.31 & 0.15 & 1.16 & 1.46 & 1.00 & 0.50 & 0.32 \\
$\mathrm{FeO}$ & 2.14 & 1.36 & 1.83 & 1.97 & 4.30 & 3.75 & 1.98 \\
$\mathrm{NiO}$ & 0.07 & 0.24 & 0.12 & 0.11 & 0.08 & 0.24 & 0.21 \\
$\mathrm{MgO}$ & 38.73 & 39.82 & 39.3 & 39.27 & 37.21 & 38.26 & 38.98 \\
$\mathrm{CaO}$ & 0.01 & 0.01 & 0.02 & 0.03 & 0.15 & - & - \\
$\mathrm{H} \mathrm{O}$ & 12.85 & 13.06 & 12.97 & 13.06 & 12.74 & 12.42 & 13.00 \\
$\mathrm{Total}$ & 99.96 & 100.67 & 100.61 & 101.55 & 99.87 & 97.22 & 100.28 \\
$\mathrm{Si}$ & 1.92 & 2.012 & 1.975 & 1.926 & 1.99 & 2.02 & 2.08 \\
$\mathrm{Ti}$ & - & - & - & - & - & - & \\
$\mathrm{Al}$ & 0.2 & 0.120 & 0.135 & 0.120 & 0.11 & 0.01 & 0.03 \\
$\mathrm{Cr}$ & 0.05 & 0.004 & 0.041 & 0.053 & 0.04 & 0.02 & 0.08 \\
$\mathrm{Fe}$ & 0.08 & 0.051 & 0.07 & 0.08 & 0.17 & 0.15 & 0.08 \\
$\mathrm{Ni}$ & - & - & - & - & 0.01 & 0.02 & 0.03 \\
$\mathrm{Mg}$ & 2.69 & 2.73 & 2.71 & 2.69 & 2.61 & 2.75 & 2.68 \\
$\mathrm{Ca}$ & - & - & - & - & - & 0.01 & \\
$\mathrm{Total}$ & 4.95 & 4.92 & 4.94 & 4.95 & 4.94 & 4.96 & 4.89 \\
\hline
\end{tabular}

Notes: $\mathrm{Atg}=$ antigorite, $\mathrm{Lz} / \mathrm{Ctl}=$ lizardite/chrysotile. $\mathrm{Fe}^{3+}$ and $\mathrm{H}_{2} \mathrm{O}$ calculated on the basis of stoichiometry.

the textural relations. It is assumed that $V_{\mathrm{mi}}^{\mathrm{Chr}}$ is the sum of chromite, ferritchromite, and its porosity. Reflected light microscopy and X-ray maps clearly show that only ferritchromite replaces chromite. The silicate matrix is assumed to be originally entirely serpentine minerals, as indicated by the serpentine relics and by the complete serpentinization of the chromitite host rock. The $V_{\mathrm{mi}}^{\mathrm{Srp}}$ is assumed to be the entire silicate matrix.

To compare the stoichiometry of reaction 3 with the observed volume changes, it is necessary to change the molar ratios represented by stoichiometric coefficients into volume ratios. The volume ratios are conveniently expressed relative to chromite using the expression:

$$
\mathrm{R}^{\mathrm{x}}=\left(\mathrm{n}^{\mathrm{x}} \cdot \mathrm{MW}^{\mathrm{x}} / \mathrm{D}^{\mathrm{x}}\right) /\left(\mathrm{n}^{\mathrm{Chr}} \cdot \mathrm{MW}^{\mathrm{Chr}} / \mathrm{D}^{\mathrm{Chr}}\right)
$$

where $\mathrm{n}^{\mathrm{x}}$ is the stoichiometric coefficient in the reaction, $\mathrm{MW}^{\mathrm{x}}$ the molecular weight, and $\mathrm{D}^{\mathrm{x}}$ the density of phase $\mathrm{x}$. Densities for each mineral are averages based on literature data (Duda and Rej1 1990). $\mathrm{R}^{\mathrm{x}}$ values are listed in Table 6. It is noteworthy that reaction 1 occurs with more than a $35 \%$ decrease in volume from chromite to ferritchromite, and this can explain the porous texture of ferritchromite. In fact, according to the modal analysis results, pore to ferritchromite ratio is around $1 / 2$, accounting for about $1 / 3$ volume loss.

Of note, $\mathrm{R}^{\text {Atg }}$ is the initial volume ratio between reactants (serpentine to chromite) to react completely to form the products. This value corresponds to an initial volume of $34.16 \%$ chromite and $65.86 \%$ serpentine (Fig. 7). All of the samples have $V_{\mathrm{mi}}^{\mathrm{Chr}}$ greater than $34.16 \%$ so that chromite is always a reactant in excess and the reaction will stop when serpentine is completely consumed.

Final modal volumes of all phases $\left(V_{\mathrm{mf}}\right)$ of all samples can be calculated assuming completion of the reaction. Because the volume of serpentine is the limiting factor and $V_{\mathrm{mi}}^{\mathrm{Chr}}>34.16 \%$, $V_{\mathrm{mf}}$ can be expressed by the following equations:

(a) $V_{\mathrm{mf}}^{\mathrm{Chl}}=V_{\mathrm{mi}}^{\mathrm{Srp}} \cdot \mathrm{R}^{\mathrm{Chl}} / \mathrm{R}^{\mathrm{Srp}}$

(b) $V_{\mathrm{mf}}^{\mathrm{Fe}-\mathrm{Chr}}=V_{\mathrm{mi}}^{\mathrm{Srp}} \cdot \mathrm{R}^{\mathrm{Fe}-\mathrm{Chr}} / \mathrm{R}^{\mathrm{Srp}}$

(c) $V_{\mathrm{mf}}^{\mathrm{Chr}}=V_{\mathrm{mi}}^{\mathrm{Chr}}-V_{\mathrm{mi}}^{\mathrm{Srp}} \cdot \mathrm{R}^{\mathrm{Chr}} / \mathrm{R}^{\mathrm{Srp}}$

(d) $V_{\mathrm{mf}}^{\mathrm{Srp}}=0$.

When the limiting phase is chromite (i.e., for chromite-bearing serpentinites), and $V_{\mathrm{i}}^{\mathrm{Chr}}<34.16 \%, V_{\mathrm{f}}$ can be expressed by the equations:

(e) $V_{\mathrm{mf}}^{\mathrm{Chl}}=V_{\mathrm{mi}}^{\mathrm{Chr}} \cdot \mathrm{R}^{\mathrm{Chl}} / \mathrm{R}^{\mathrm{Chr}}$

(f) $V_{\mathrm{mf}}^{\mathrm{Fe}-\mathrm{Chr}}=V_{\mathrm{mi}}^{\mathrm{Chr}} \cdot \mathrm{R}^{\mathrm{Fe}-\mathrm{Chr}} / \mathrm{R}^{\mathrm{Chr}}$

(g) $V_{\mathrm{mf}}^{\mathrm{Chr}}=0$

(h) $V_{\mathrm{mf}}^{\mathrm{Srp}}=V_{\mathrm{mi}}^{\mathrm{Srp}}-V_{\mathrm{mi}}^{\mathrm{Chr}} \cdot \mathrm{R}^{\mathrm{Chr}} / \mathrm{R}^{\mathrm{Chr}}$.

In a $V_{\mathrm{mi}}^{\mathrm{Chr}}$ vs. $V_{\mathrm{mf}}$ diagram for all phases, the mass balance expressions related to these two conditions define two fields, each of which has guidelines for the likely volumetric amounts of products and reactants (Fig. 7). For the $V_{\mathrm{mi}}^{\mathrm{Chr}}<34.16 \%$, the limiting phase is chromite such that final volumes of reactants are negatively correlated to $V_{\mathrm{mi}}^{\mathrm{Chr}}$ and final volumes of products are positively correlated to $V_{\mathrm{mi}}^{\mathrm{Chr}}$. In contrast, for the $V_{\mathrm{mi}}^{\mathrm{Chr}}>$ $34.16 \%$ limiting condition, serpentine controls the final volumes of reactants that are positively correlated to $V_{\mathrm{mi}}^{\mathrm{Chr}}$, whereas the final volumes of products are negatively correlated to $V_{\mathrm{mi}}^{\mathrm{Chr}}$. The deviation between the theoretical lines and observed $V_{\mathrm{mf}}$ of each sample is generally relatively minor, but $V_{\mathrm{mf}}$ are consistently lower than $V_{\mathrm{mf}}$ for products (chromian-chlorite and ferritchro- 

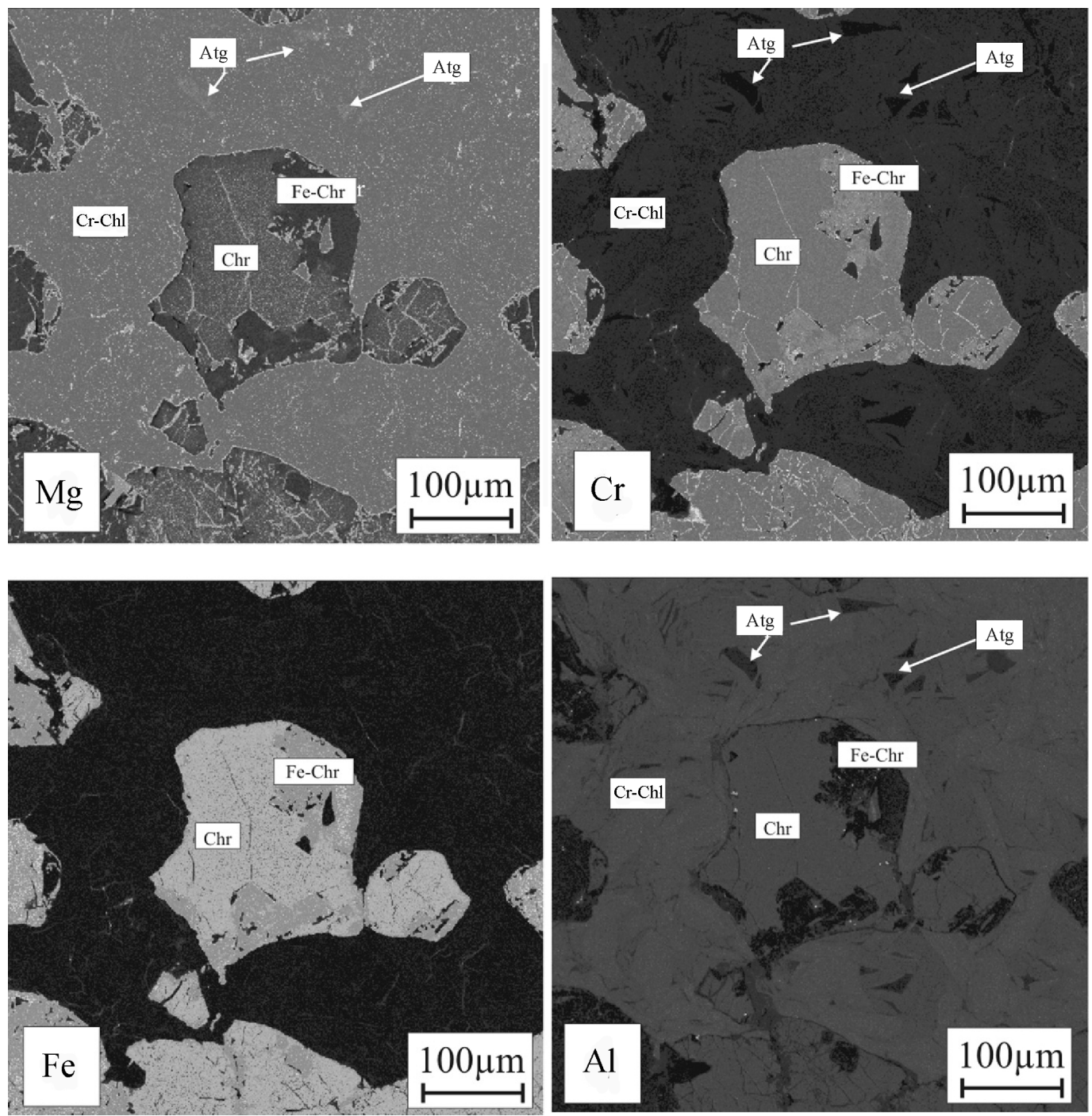

FigURE 6. X-ray element map showing the distribution of $\mathrm{Mg}, \mathrm{Cr}, \mathrm{Fe}$, and $\mathrm{Al}$. Dark colors correspond to low concentrations; bright colors correspond to high concentrations. $\mathrm{Chr}=$ chromite, $\mathrm{Fe}-\mathrm{Chr}=$ ferritchromite, $\mathrm{Cr}-\mathrm{Chl}=$ chromian-chlorite, $\mathrm{Atg}=$ antigorite.

TABLE 5. Modal analysis results

\begin{tabular}{|c|c|c|c|c|c|c|c|c|}
\hline \multirow[t]{2}{*}{ Sample } & \multirow[t]{2}{*}{ Texture } & \multicolumn{3}{|c|}{ Areas $\left(\mathrm{mm}^{2}\right)$} & \multirow[t]{2}{*}{ Tot. area } & \multicolumn{3}{|c|}{$V_{m f} \%$} \\
\hline & & $\mathrm{Cr}-\mathrm{Chl}$ & $\mathrm{Chr}$ & $\mathrm{Fe}-\mathrm{Chr}$ & & $\mathrm{Cr}-\mathrm{Chl}$ & $\mathrm{Chr}$ & Fe-Chr \\
\hline <2D-2 & D & 18.71 & 23.95 & 4.44 & 4 & 39.72 & 50.85 & 9.43 \\
\hline 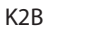 & DD & & 27.35 & 2.1 & & 55 & 57.93 & 4.52 \\
\hline 13 & DD & 7.26 & 26.91 & 2.5 & & 6.98 & 57.63 & 5.40 \\
\hline K2D & DD & 4.54 & 28.82 & 3.78 & & 0.84 & 61.14 & 8.02 \\
\hline & D & 6 & 28. & 3.2 & & & 61.64 & 6.91 \\
\hline $2 \mathrm{~A}-1$ & DD & 1.09 & 30.13 & 3.08 & 47 & 29.78 & 63.70 & 6.51 \\
\hline & DD & 87 & 30.41 & 1.5 & & 77 & 64.97 & 3.26 \\
\hline & M & & 38 & 1.6 & & 5 & 80.62 & 3.40 \\
\hline K4A-3 & M & 4.25 & 41.18 & 1.69 & 47.12 & 9.02 & 87.40 & 3.58 \\
\hline K4A & M & 3.22 & 43.78 & 0.21 & 47.21 & 6.82 & 92.74 & 0.45 \\
\hline
\end{tabular}

Notes: $\mathrm{D}=$ disseminated, $\mathrm{DD}=$ densely disseminated, $\mathrm{M}=$ massive textures, and $V_{\mathrm{mf}}=$ modal final volume. $\mathrm{Cr}-\mathrm{Chl}=$ chromian-chlorite, $\mathrm{Chr}=$ chromite, $\mathrm{Fe}-\mathrm{Chr}$ $=$ ferritchromite.

mite) and higher for reactants (chromite). This suggests that the reaction, although very close to completion, never fully reaches it, leaving small, unreacted areas, as indicated by the presence of minor serpentine relics in the silicate matrix. It is likely that during the final stages of reaction the distance between reactants
TABLE 6. Relative volumes

\begin{tabular}{llllll}
\hline Phase & \multicolumn{1}{c}{ Formula } & $\mathrm{n}$ & $\mathrm{MW}$ & $\mathrm{D}$ & \multicolumn{1}{c}{$\mathrm{R}^{\mathrm{x}}$} \\
\hline $\mathrm{Chr}$ & $\left(\mathrm{Mg}_{0.60} \mathrm{Fe}_{0.40}\right)\left(\mathrm{Cr}_{1.30} \mathrm{Al}_{0.70}\right) \mathrm{O}_{4}$ & 2 & 187.35 & 4.43 & 100 \\
Atg & $\left(\mathrm{Mg}_{2.57} \mathrm{Al}_{0.32} \mathrm{Fe}_{0.11}\right) \mathrm{Si}_{2} \mathrm{O}_{5}(\mathrm{OH})_{4}$ & $3 / 2$ & 281.43 & 2.59 & 192.70 \\
$\mathrm{Fe}-\mathrm{Chr}$ & $\left(\mathrm{Fe}_{0.60} \mathrm{Mg}_{0.40}\right)\left(\mathrm{Cr}_{1.85} \mathrm{Fe}_{0.08} \mathrm{Al}_{0.07}\right) \mathrm{O}_{4}$ & $7 / 6$ & 209.7 & 4.50 & 64.28 \\
$\mathrm{Cr}-\mathrm{Chl}$ & $\left(\mathrm{Mg}_{9.18} \mathrm{Fe}_{0.34} \mathrm{Al}_{1.60} \mathrm{Cr}_{0.88}\right)\left(\mathrm{Al}_{2} \mathrm{Si}_{6}\right) \mathrm{O}_{20}(\mathrm{OH})_{16}$ & $1 / 2$ & 1145.53 & 2.60 & 255.54 \\
\hline Note: $\mathrm{Chr}=$ chromite, $\mathrm{Atg}=$ antigorite, $\mathrm{Fe}-\mathrm{Chr}=$ ferritchromite, $\mathrm{Cr}-\mathrm{Chl}=$ chromian- \\
chlorite, $\mathrm{n}=$ stoichiometric coefficient, $\mathrm{MW}=$ molecular weight, $\mathrm{D}=$ density, $\mathrm{R}^{\mathrm{x}}$ \\
= relative volume.
\end{tabular}

is great enough to prevent completion of the reaction. Furthermore, there is a greater distance between serpentine relics and chromite grains. Consequently, the presence of ferritchromite that partially replaces the original chromite within chromitites is not the result of an incomplete reaction, but rather a function of the amount of available serpentine.

\section{Metamorphic evolution}

Chromite is commonly the only igneous phase that survives replacement processes. However, as observed in Kalkan chro- 


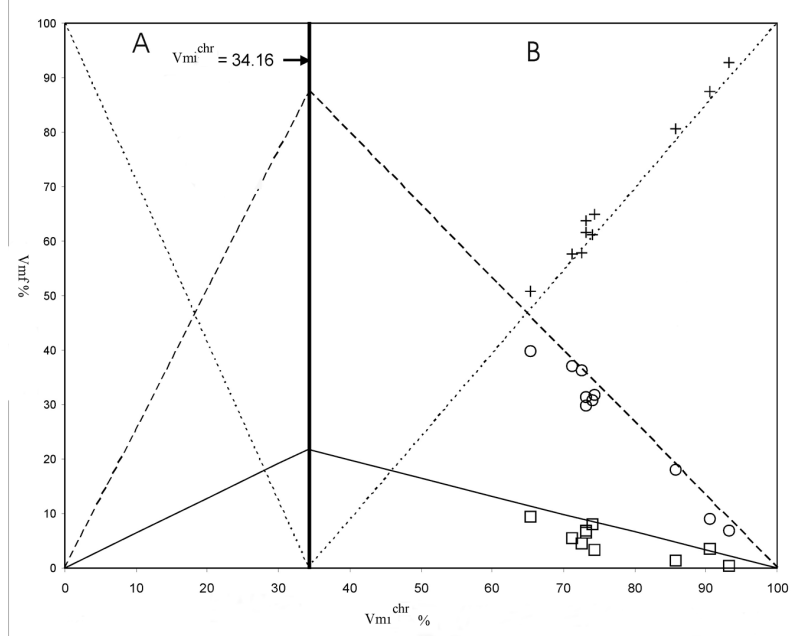

FIGURE 7. Initial modal volume percent of chromite $\left(V_{\mathrm{mi}}^{\text {chr }}\right)$ vs. final modal volume $\left(V_{\mathrm{mf}}\right)$ of chromian-chlorite (dashed line), ferritchromite (solid line), and antigorite in $\mathbf{a}$ (dotted line) and chromite in $\mathbf{b}$ (dotted line). Squares $=$ modal volumes of ferritchromite, circles $=$ modal volumes of chromian-chlorite, crosses $=$ modal volume of chromite. (a) Illustrates samples where $V_{\mathrm{mi}}^{\mathrm{Chr}}$ is $<34.16$ and chromite is the limiting agent of reaction; in this case, reaction will stop after complete consumption of chromite. (b) Illustrates samples where $V_{\mathrm{mi}}^{\mathrm{Chr}}$ is $>34.16$ and antigorite is the limiting agent of reaction; in this case, reaction will stop after complete consumption of antigorite.

mitites, geochemical features may change during later metamorphic overprinting resulting in secondary alteration products such as ferritchromite and chromian-chlorite (Pouyan et al. 1988; O’Hanley and Dyar 1993; Proenza et al. 1999; Nozaka 2003; Palandri and Reed 2004; Bach et al. 2006; Caillaud et al. 2006).

Chromite replacement by ferritchromite can be a useful tool to investigate the metamorphic evolution of the host rock. At Kalkan, ferritchromite does not form rims that grow around chromite but is a porous phase that has replaced chromite. Such replacement is partial because the reaction does not convert all of the reactants and the environment acts as a closed system with the exception of fluids. Formation of ferritchromite and chromian-chlorite in the Kalkan chromitites cannot be viewed as a low-temperature alteration process occurring after serpentinization. It is a result of prograde metamorphism after a previous low-temperature serpentinization.

A three-stage evolution can be used to explain ferritchromite formation in the Kalkan chromitites. The first stage is related to the equilibration of chromite grains with surrounding olivine. The thermodynamic model of Sack and Ghiorso (1991), allows calculation of spinel stability fields via a geothermometer based on $\mathrm{Mg}$ and $\mathrm{Fe}$ exchange between olivine and spinel. The stability limits for chromite in equilibrium with olivine can be calculated assuming a theoretical olivine of composition $\mathrm{Fo}_{90}$ (the average Fo of olivine from the nearby Kalkan massif peridotites). Results for chromite cores give a temperature range appropriate for the upper greenschist-amphibolite facies with a temperature close to $550^{\circ} \mathrm{C}$. This temperature can be viewed as the final equilibrium temperature after olivine-spinel exchange on cooling (Henry and Medaris 1980) (Fig. 8). The second stage is represented by complete serpentinization of the chromitite matrix at low temperature, as indicated by the presence of low-temperature relics of lizardite/chrysotile. As proposed by Hajialioghli et al. (2007) and Auzende et al. (2006), such a process takes place at around $200-300{ }^{\circ} \mathrm{C}$ where low-temperature lizardite/chrysotile are stable. Magnetite probably does not form due to the massive texture of this type of rock where interstitial silicates (olivine and pyroxene) are significantly less abundant with respect to chromite crystals. In this case, the iron released during the serpentinization process by olivine is not enough to form magnetite.

In the third stage, prograde metamorphism at temperatures above $300{ }^{\circ} \mathrm{C}$ will transform most lizardite/chrysotile into the high-temperature polymorph antigorite. The chromite-serpentine assemblage is transformed into the observed ferritchromitechromian-chlorite assemblage as controlled by metamorphic reaction 3 in the presence of an aqueous fluid phase. Such a scenario for the production of the ferritchromite-chromian-chlorite association can better explain why many chromitites do not contain ferritchromite and chromian-chlorite. The suggestion is that they were not subjected to higher temperature metamorphic overprints after serpentinization.

\section{CONCLUDING REMARKS}

Ferritchromite and chromian-chlorite formation after chromite and serpentine are due to a prograde metamorphic reaction that commonly goes unnoticed because of the rarity of chromitites in mantle rocks as well as the proportions of reactant phases. In serpentinites, high serpentine to spinel ratios dictate that this reaction will form only small chlorite rims around spinel grains. Most serpentine will be unreacted in chromitites as a result of their low serpentine to chromite ratios, and only small portions of chromite will be tranformed into ferritchromite. Reactions usually involve only small volumes of rock so most serpentine will be unreacted in serpentinites and most chromite will be unreacted in chromitites. The proposed isochemical reaction is based on actual textural and chemical data leads to millimeter-to-centimeter

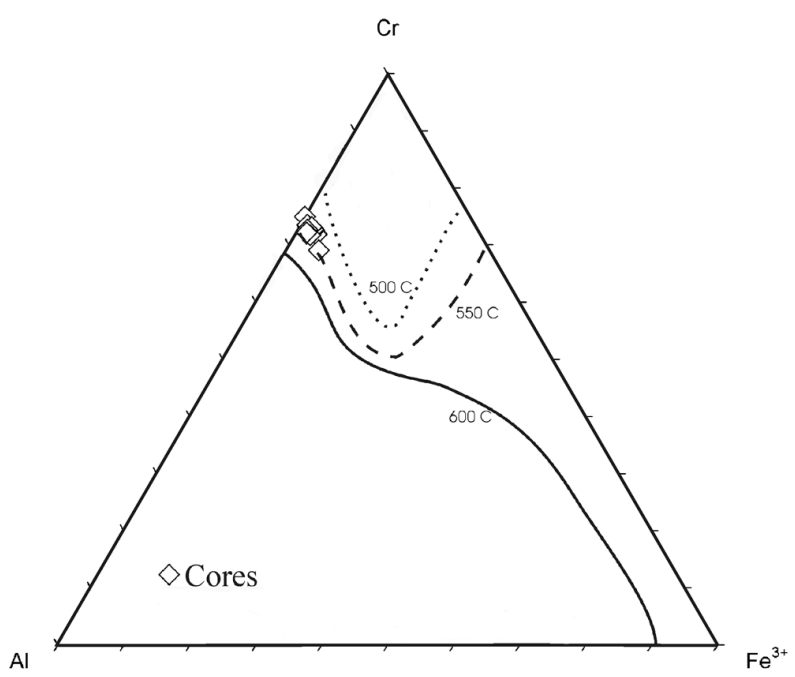

FIGURE 8. Spinel stability limits for ferritchromite calculated for equilibrium with olivine of composition $\mathrm{Fo}_{90}$ at 500 , 550, and $600{ }^{\circ} \mathrm{C}$ (Sack and Ghiorso 1991). Selected chemical analyses of ferritchromite cores from the Kalkan chromitite are shown in diamonds. 
scale redistribution of $\mathrm{Cr}$ and $\mathrm{Fe}^{3+}$ (enriched in ferritchromite) and $\mathrm{Al}$ and $\mathrm{Mg}$ (enriched in chromian-chlorite).

Evidence from Kalkan chromitites show that the chromianchlorite formation is related to prograde metamorphic conditions occurring after serpentinization. Considering the geodynamic evolution of Kalkan ophiolite, the most likely geodynamic environment in which such a process could have occurred is within the accretionary wedge where slices of serpentinized oceanic lithosphere were accreted, strongly deformed, and metamorphosed.

The results of this study can be important in chromite ore processing since partial redistribution of $\mathrm{Cr}$ within silicates negatively affects the efficiency of chromite gravimetric enrichment plants. This study shows that even within the same chromite deposit that underwent the Fe-chromite + chromian-chlorite formation, loss of $\mathrm{Cr}$ due to its redistribution in silicates will be much more effective in schlieren and scattered chromitites than in massive chromitites.

\section{ACKNOWLEDGMENTS}

We thank Galina Savelieva and Nadezhda Chaplygina from Moscow branch of Russian Academy of Sciences for their help during fieldwork in the Russian Federation.

\section{REFERENCES CITED}

Arai, S. (1992) Chemistry of chromium spinel in volcanic rocks as a potential guide to magma chemistry. Mineralogical Magazine, 56, 173-184.

(1994) Characterization of spinel peridotite by olivine-spinel compositional relationships: review and interpretation. Chemical Geology, 113 191-204.

Auzende, A.L., Guillot, G., Devouard, B., and Baronnet, A. (2006) Behaviour of serpentinites in convergent context: Microstructural evidences. European Journal of Mineralogy, 18, 21-33.

Bach, W., Paulick, H., Garrido, C.J., Ildefonse, B., Meurer, W.P., and Humphris, S.E. (2006) Unraveling the sequence of serpentinization reactions: petrography, mineral chemistry, and petrophysics of serpentinites from MAR $15^{\circ} \mathrm{N}$ (ODP Leg 209, Site 1274). Geophysical Research Letters, 33, L13306, DOI: 10.1029/2006GL025681.

Barnes, S.J. (2000) Chromite in komatiites, II. Modification during greenschist to mid-amphibolite facies metamorphism. Journal of Petrology, 41, 387-409.

Barnes, S.J. and Roeder, P.L. (2001) The range of spinel composition in terrestrial mafic and ultramafic rocks. Journal of Petrology, 42, 2279-2302.

Burkhard, D.J.M. (1993) Accessory chromium spinels: Their coexistence and alteration in serpentinites. Geochimica et Cosmochimica Acta, 57, 1297-1306.

Caillaud, J., Proust, D., and Righ, D. (2006) Weathering sequences of rockforming minerals in a serpentinite; influence of microsystems on clay mineralogy. Clays and Clay Minerals, 54, 87-100.

Cassard, D., Nicolas, A., Rabinovitch, M., Moutte, J., Leblanc, M., and Prinzhofer, A. (1981) Structural classification of chromite pods in southern New Caledonia. Economic Geology, 76, 805-831.

Chaplygina, N.L., Degtyarev, K.E., and Savelieva, G.N. (2002) Harzburgite type ophiolites in the structurated melange of the west Magnitogorsk Zone in the Southern Urals. Geotectonics, 36, 451-462.

Christofides, G., Thimiatis, G., Koroneos, A., Sklavounos, S.N.S., and Eleftheriadis, G. (1994) Mineralogy and chemistry of Cr-chlorites associated with chromites from Vavdos and Vasilika ophiolite complexes (Chalikidiki, Macedonia, N. Greece). Chemie der Erde, 54, 151-166.

Dick, H. and Bullen, T. (1984) Chromian spinel as a petrogenetic indicator in abyssal and alpine-type peridotites and spatially associated lavas. Contributions to Mineralogy and Petrology, 86, 54-76.

Duda, R. and Rejl, L. (1990) Mineral of the World. Arch Cape Press, New York.

Evans, B. and Frost, R.B. (1975) Chrome spinel in progressive metamorphism: A preliminary analysis. Geochimica et Cosmochimica Acta, 39, 959-972.

Hajialioghli, R., Moazzen, M., Droop, G.T.R., Oberhansli, R., Bousquet, R., Jahngri, A., and Ziemann, M. (2007) Serpentine polymorphs and $P-T$ evolution of metaperidotites and serpentine in the Takab area, NW Iran. Mineralogical Magazine, 71, 203-222.

Henry, D.J. and Medaris Jr., L.G. (1980) Application of pyroxene and olivine-spinel geothermometers to spinel peridotites in southwestern Oregon. American
Journal of Science, 280-A, 211-231

Higgins, M.D. (2006) Quantitative Textural Measurements in Igneous and Metamorphic Petrology, 270 p. Cambridge University Press, U.K.

Hoffman, M.A. and Walker, D. (1978) Textural and chemical variations of olivine and chrome spinel in the East Dover ultramafic bodies, south-central Vermont. Geological Society of America Bulletin, 89, 699-710.

Irvine, T.N. (1965) Chromian spinel as a petrogenetic indicator. Part I. Theory. Canadian Journal of Earth Science, 2, 648-72.

(1967) Chromian spinel as a petrogenetic indicator. Part II. Petrological applications. Canadian Journal of Earth Science, 4, 71-103.

Kimball, K.L. (1990) Effects of hydrothermal alteration on the composition of chromian spinels. Contribution to Mineralogy and Petrology, 105, 337-346.

Loferski, P.J. and Lipin, B.R. (1983) Exolution in metamorphosed chromite from the Red Lodge district, Montana. American Mineralogist, 68, 777-789.

Malpas, J. (1992) Serpentine and the geology of serpentinized rocks. In B.A. Roberts and J. Proctor, Eds., The Ecology of Areas with Serpentinized Rocks. A World View, p. 7-30. Kluwer Academic Publisher, Netherlands.

Mattioli, G.S. and Wood, B.J. (1988) Magnetite activities across the $\mathrm{MgAl}_{2} \mathrm{O}_{4}-\mathrm{Fe}_{3} \mathrm{O}_{4}$ spinel join, with application to thermobarometric estimates of the upper mantle oxygen fugacity. Contributions to Mineralogy and Petrology, 98, 148-162.

Mellini, M., Rumori, C., and Viti, C. (2005) Hydrothermally reset magmatic spinels in retrograde serpentinites, formation of "ferritchromit" rims and chlorite aureoles. Contributions to Mineralogy and Petrology, 149, 266-275.

Nozaka, T. (2003) Compositional heterogeneity of olivine in thermally metamorphosed serpentinite from Southwest Japan. American Mineralogist, 88, 1377-1384.

O'Hanley, D.S. and Dyar, M.D. (1993) The composition of lizardite 1T and the formation of magnetite in serpentinites. American Mineralogist, 78, 391-404.

O'Neill, H.St.C. and Wall, V.J. (1987) The olivine-orthopyroxene-spinel oxygen geobarometer, the nickel precipitation curve, and the oxygen fugacity of the Earth's upper mantle. Journal of Petrology, 28, 1169-1191.

Onyeagocha, A.C. (1974) Alteration of chromite from the Twin Sister Dunite, Washington. American Mineralogist, 59, 608-612.

Ozawa, K. (1983) Evaluation of olivine-spinel geothermometry as an indicator of thermal history for peridotites. Contributions to Mineralogy and Petrology, 82, 52-65.

Oze, C., Fendorf, S., Bird, D., and Coleman, R. (2004) Chromium geochemistry in serpentinized ultramafic rocks and serpentine soils from the Franciscan complex of California. American Journal of Science, 304, 67-101.

Palandri, J.L. and Reed, M.H. (2004) Geochemical models of metasomatism in ultramafic systems: serpentinization, rodingitization, and sea floor carbonate chimney precipitation. Geochimica et Cosmochimica Acta, 68, 1115-1133.

Poustovetov, A.A. (2000) Numerical modeling of chemical equilibria between chromian spinel, olivine, and basaltic melt, with petrologic applications, 135 p. Ph.D. thesis, Queen's University, Kingston, Ontario.

Pouyan, S., Shyn-Lung, H., Hao-Tsu, C., and Ruey-Chang, J. (1988) STEM study of "ferritchromit" from the Heng-Chun Chromitite. American Mineralogist, $73,383-388$

Proenza, J., Solè, J., and Melgarejo, J.C. (1999) Uvarovite in podiform chromitite, the Moa Baracoa ophiolitic massif, Cuba. Canadian Mineralogist, 37, 679-690.

Sack, R.O. and Ghiorso, M.S. (1991) Chromian spinels as petrogenetic indicators: Thermodynamics and petrological applications. American Mineralogist, $76,827-847$.

Saveliev, A.A., Astrakhantsev, O.V., Knipper, A.L., Sharaskin, A.Ya, and Savelieva, G.N. (1998) Structure and deformation phases of the northern terminus of the Magnitogorsk zone, Urals. Geotectonics, 32, 201-212.

Spangeberg, K. (1943) Die Chromietlagerstatte vom Tampadel in Zobten. Zeitschr Parkt Geologie, 5, 13-35.

Thayer, T.P. (1964) Principal features and origin of podiform deposits, and some observations on the Guleman-Soridag district, Turkey. Economic Geology, $59,1497-1524$

Ulmer, G.C. (1974) Alteration of chromite during serpentinization in the Pennsylvania Maryland District. American Mineralogist, 59, 1236-1241.

Wicks, F.J. and Whittaker, E.J.W. (1977) Serpentine textures and serpentinization. Canadian Mineralogist, 15, 459-488.

Wood, B.J. (1990) An experimental test of the spinel peridotite oxygen barometer. Journal of Geophysical Research, 95, 15845-15851.

MANUSCRIPT RECEIVED AUGUST 29, 2008

MANUSCRIPT ACCEPTED JUNE 9, 2009

MANUSCRIPT HANDLED BY DARRELL HENRY 